\title{
A Mapping of the Present and Past Forest-types of Prince Edward Island
}

\author{
D. G. SOBEY ${ }^{1}$ AND W. M. GLEN ${ }^{2}$
}

${ }^{1}$ School of Applied Biological and Chemical Sciences, University of Ulster, Jordanstown, Northern Ireland BT37 0QB United Kingdom. (Research Associate of the Institute of Island Studies, University of Prince Edward Island, Charlottetown, Prince Edward Island)

${ }^{2}$ Natural Resources Division, Department of Agriculture and Forestry, PO Box 2000, Charlottetown, Prince Edward Island C1A 7 N8 Canada

Sobey, D. G., and W. M. Glen. 2004. A mapping of the present and past forest-types of Prince Edward Island. Canadian Field-Naturalist 118(4): 504-520.

Our aim was to produce maps showing the distribution on Prince Edward Island of five forest-types previously identified from a TWINSPAN analysis of ground flora data collected at 1200 sampling points in a field survey. For this purpose we had available two databases: one on the composition of the tree canopy of 82957 forest stands, as determined by photointerpretation of a 1990 aerial photographic survey of the island; the other on the drainage properties of the same stands from a published soil survey. The tree canopy and drainage criteria for sorting these stands into five stand-types were chosen in the light of the equivalent properties of the TWINSPAN forest-types as evident from the field survey. These criteria were perfected in four trial computer-sortings, followed by the computer-printing of maps showing the distribution of the standtypes. These maps, which were then evaluated by comparing them with the properties of the TWINSPAN forest-types, are the first fine-scale maps of the main forest-types of the island. They reveal that, of the three "primary" forest-types, the upland hardwood forest occurs especially in the central and south-eastern hill-lands, as well as in scattered parcels elsewhere, whereas the Black Spruce forest and the wet species-rich woodland occur primarily in areas of lower elevation in the east and west of the island. The two forest-types resulting from human disturbance, the White Spruce woods and the "disturbed forest", have a more scattered distribution, with the White Spruce woods being found especially in the central and eastern parts of the island and the disturbed forest in the west and east of the island. A secondary aim was to map the conjectured distribution before European settlement of the three primary forest-types: two maps have been produced, one showing the distribution of upland hardwood forest, the other of the wet forest-types.

Key Words: forest classification, forest mapping, forest history, Prince Edward Island.

Between 1990 and 1992 the Prince Edward Island Forestry Division carried out a comprehensive Forest Biomass Inventory of the province, a component of which was a field survey in 1991 at 240 randomlyselected forest sites. At each of the sites the percentage cover of the ground flora species in $4-\mathrm{m}^{2}$ plots was recorded at five sampling points. The availability of such ground flora data from such a large number of plots (1200 in total) presented an unprecedented opportunity for the study and analysis of the woodland ground vegetation and forest-types of Prince Edward Island.

An earlier paper (Sobey and Glen 2002) presented an analysis of the ground flora data in 1127 of the plots using two multivariate techniques: TWINSPAN - two-way indicator species analysis (a classification technique), and DECORANA - detrended correspondence analysis (an ordination technique). TWINSPAN led to the recognition of five forest-types, each characterized by particular tree species and soil drainage properties: (1) a wet species-rich swamp-type woodland, (2) upland hardwood forest, (3) Black Spruce (Picea mariana) forest, (4) old field White Spruce (Picea glauca) woods, and (5) disturbed conifer-dominated forest. It was conjectured that the first three of these forest-types were heavily modified descendants of forest-types occurring at the time of European settlement, while the two latter appeared to be largely the product of successional processes associated with the effects of human disturbance and forest clearance. The DECORANA ordination provided further support for the overall importance of soil drainage and human disturbance as the principal factors responsible for the differences between the five forest-types.

The aim of this paper is to expand the results of the plant community analysis beyond the 1200 sampling points to include the whole forested area of the island, in the form of maps showing the total distribution of the five forest-types on the island. Since the forest-types were initially segregated and defined by TWINSPAN on the basis of the composition of their ground flora, the ideal mapping approach would have been to use the ground flora composition of all forest stands on the island as the basis for mapping the distribution of the forest-types. However, such data are not available for the whole forested area of the island and are never likely to be. The forest-types thus had to be mapped using data that showed a correlation with the ground flora composition (i.e., data on the composition of the tree canopy) and also for some, data on soil drainage properties. It is fortunate that there were available two comprehensive relevant databases for the 
whole island: the more important was a database on the tree species composition of all forest stands on the island, based on an aerial photographic survey carried out in mid-summer 1990; the other was the Prince Edward Island Soil Survey (MacDougall et al. 1988) which classified the soils of the island into 44 soil series and mapped their distribution (at a scale of 1:10 000) over the whole island. The soil survey proved useful in the forest mapping because some of the TWINSPAN forest-types had high levels of association with particular soil drainage properties.

It should be noted that none of the previous attempts at forest classification and mapping that include Prince Edward Island (Stilgenbauer 1929; Halliday 1937; Rowe 1959; Loucks 1962) aimed to map what was actually present on specific sites, nor do they contain a high level of detail or accuracy. Halliday's and Rowe's maps, being part of national studies, show no internal differentiation at all in the forests of the island. Loucks (working at the level of Maritime forests), did subdivide the island's forests: he placed them in three "forest districts" but the boundaries of these are very generalized on his map. One comprised the hardwood areas of the central and eastern parts of the island; the other two were coniferous districts: one in the west along the shores of Northumberland Strait, the other running along the length of the northern shore. The map showing the greatest detail (Stilgenbauer 1929) is actually the earliest of the four, but Stilgenbauer's descriptions of his "forest belts" are brief and qualitative and the criteria he used for delimiting them are not given. In addition to these mapping studies, there is a useful descriptive summary of the forest-types of the island in Erskine (1960), and in Appendix 1 the stand-types emerging from this study are equated with Erskine's descriptions.

The principal objective of this study was thus, making use of two comprehensive databases, to map the total distribution on Prince Edward Island of the five forest-types recognized in a TWINSPAN analysis, and to further verify the validity of the maps by comparing the properties of the mapped stands with those of the TWINSPAN forest-types. Such a mapping will not only give us a clear picture of the current actual distribution on the ground of the main forest-types on the island, but should also assist us in understanding the factors responsible for their distributions. A secondary objective (on the basis of any stand and soil relationships that might emerge) was to attempt to extend the mapping back into historical time in order to obtain a picture of the possible distribution of the forest-types before the advent of the large scale forest clearance that began in the eighteenth century with the beginning of European settlement on the island.

\section{Methods}

The methodology leading to the description of the forest-types and their mapping makes use of several large independently obtained databases and involves a number of different stages in processing and analysing the data they contain. Figure 1 shows these databases and stages in diagrammatic form. The end-product, computer-produced maps of the five forest-types, is the result of a computer-sorting of 82957 demarcated stands of "high forest" (i.e., excluding alder woods, plantations, clear-cut and burned areas) into five foresttypes on specific tree canopy and soil drainage criteria. In the description of the various steps in the analysis, the text that follows is linked to the stages shown in Figure 1 by Roman numerals in square brackets, e.g.: [I].

\section{The databases:}

\section{The 1991 field survey: ground flora and tree canopy} data

Of the vast amount of data collected at the 1200 sampling points in the 1991 field survey, two data sets, one on the ground flora [II], the other on the tree canopy [III], are of relevance to this report. We present here only a summary of the methods used to collect these data - full field methods are given in Sobey and Glen (2002).

The data were collected between June and September 1991 at 1200 ground flora plots located at 240 randomly-selected forest sites. At each sampling point the tree canopy was assessed using a "point sampling" technique involving the use of a "variableradius plot" centred on the sampling point (Watts 1983). From these field data, the percentage contribution of each tree species to the total woody biomass (to the nearest $10 \%$ ) in each variable radius plot was calculated [III]. The ground flora species were assessed within a circular 4- $\mathrm{m}^{2}$ plot, with each species being given a percentage cover value to the nearest $10 \%$, with a minimum value of $5 \%$ [II].

The TWINSPAN classification and the recognition of five forest-types

The TWINSPAN classification of 1127 of the 1200 ground flora plots (based on the species composition and percentage cover of their ground flora species) resulted in the recognition of 11 ground flora plot groups or community-types [V] (see Sobey and Glen (2002) for a full description of the methodology note that 73 plots were omitted from the analysis either because no trees were recorded in the area of the sampling point, or because no ground flora species were present in the $4-\mathrm{m}^{2}$ plot). These plot groups were then examined in terms of the species composition of the tree canopy and other properties at the sampling sites (especially soil drainage), and as a result five major forest-types were recognized [VII]. (See Sobey and Glen (2002) for summary descriptions of each of these forest-types and maps showing the distribution of their sampling points on the island.)

\section{The 1990 aerial survey: the forest stand database}

Complete aerial photographic coverage of the island was carried out in mid-summer 1990 as part of 


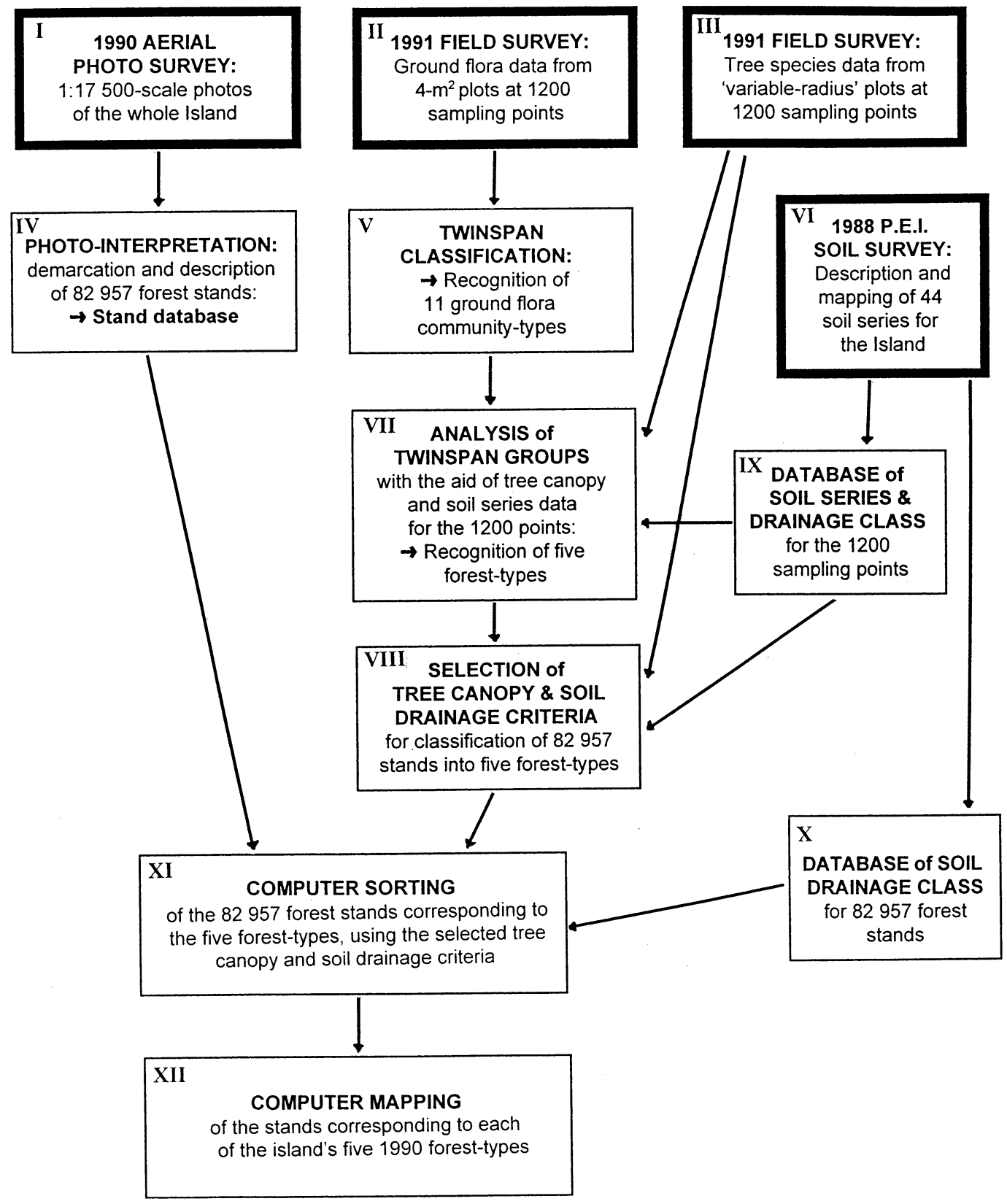

FIGURE 1. The stages leading to the mapping of the 1990 forest-types on Prince Edward Island: a flow diagram showing the databases used (in the boxes with heavy borders) and the analyses carried out.

the 1990-1992 Prince Edward Island Forest Biomass Inventory [I]. The false-colour infra-red photographs resulting from the survey (scale $c .1: 17$ 500) were analysed by trained photo-interpreters in the Forestry Division with the purpose of dividing the total forested area into "stands" which were then recorded on a map as "polygons" [IV]. For the purpose of the photo-interpretation, a stand was taken to be a group of trees having a relatively uniform visual appearance from the air as evident in the aerial photograph. Stands could comprise a single species or several or many species, but they are generally of a uniform species composition, height and density. For each of the 82957 stands, up to five tree species, each con- 


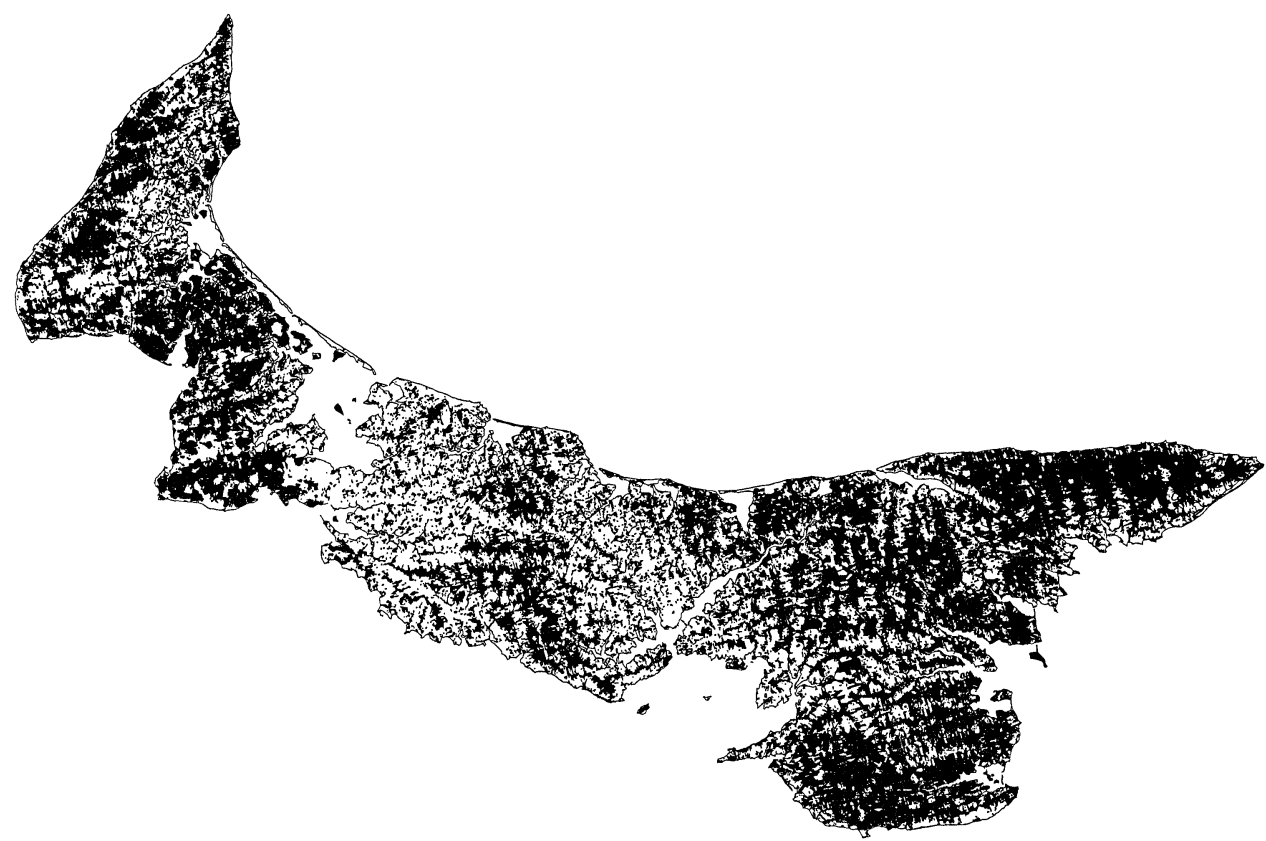

FIGURE 2. The distribution of "high forest", based on photo-interpretation of the 1990 aerial photographic survey of the island. (High forest excludes Speckled Alder woods, plantations, and clear-cut and burned areas.)

tributing greater than 5\% crown closure to the canopy, were recorded, with the percentage contribution of each species being estimated to the nearest $10 \%$. The database resulting from the photo-interpretation was computerised, and the stand boundaries were linked to the Geographic Information System (G.I.S.) for the province, enabling the direct plotting onto maps of stand boundaries and areas, as well as the extraction of data on their tree species make-up.

3. The 1988 soil survey of Prince Edward Island: a soil series database

The most recent major soil survey of the island (MacDougall et al.1988) has resulted in the classification of the island's soils into 44 soil types or "series", and the mapping (scale: 1:10 000) of the distribution of these series over the whole island [VI]. The soil maps have been digitized in the G.I.S. for the island, such that the soil series at each of the sampling points in the 1991 field survey [IX], as well as for each forest stand polygon in the aerial stand database [X], are accessible by computer. For this study it was decided that it would also be useful to group the 44 soil series into six drainage classes: rapidly-drained, welldrained (coarse-textured parent materials), welldrained (medium-textured parent materials), imperfectly-drained, poorly-drained, and organic soils.

Selection of the tree canopy and soil drainage criteria.

The selection of the criteria for dividing the 82957 stands of high forest (i.e., the area shown in Figure 2) into the five forest-types [VIII] (or "stand-types" as they will be termed to distinguish them from the TWINSPAN-defined forest-types), was based on the tree canopy and soil drainage properties of the five TWINSPAN forest-types as evident from the 1991 field survey (Sobey and Glen 2002). Four trial computer sortings on selected criteria were carried out in succession; the results of each trial were evaluated and the criteria for each of the five stand-types were then redefined and a new sorting was carried out. Eventually the perfected criteria were chosen (Table 1 ), and all of the stands in the database were computer-sorted on these criteria [XI], followed by the computer-printing of maps showing the distribution of each stand-type on the island [XII]. It should be noted that in any of the sortings the order of the sort (i.e., of the selecting and removal of each stand-type) is important, since once a stand has been sorted it is normally no longer available for inclusion in subsequent stand-types even if it should meet their particular criteria. The following is a more detailed discussion of the criteria used for each of the five forest-types, as well as of some of the changes made as a result of the trial sortings:

1. Upland hardwood forest. In the TWINSPAN classification Sugar Maple (Acer saccharum) and American Beech (Fagus grandifolia) had been virtually restricted to sampling points belonging to the upland hardwood forest-type (Sobey and Glen 2002). Yellow 
TABLE 1. The criteria used in the sorting of 82957 stands of "high forest" on Prince Edward Island into five stand-types corresponding to the five forest-types recognized in a TwINSPAN classification of 1127 ground flora plots.

SELECT ANd Remove: stands designated as clear-cut, burned, plantation, windfall, or alder. This leaves 82957 stands of "high forest"

FIRST SorT: Excluding any stands containing White Ash, Eastern White Cedar or White Elm, select all stands containing Sugar Maple, American Beech or Eastern Hemlock, plus all stands with Yellow Birch, but for the last species excluding those stands on poorly-drained, imperfectly-drained or organic soils.

\section{Upland hardwood forest}

SECOND SoRT: Excluding any stands containing White Ash, Eastern White Cedar or White Elm, select all stands containing Black Spruce with crown closure $\geq 50 \%$.

2. Black Spruce forest

ThIRD SorT: Select all stands containing White Elm, White Ash, or Eastern White Cedar, and/or classed as 'swampy', plus all stands with a crown closure of total hardwoods $\geq 50 \%$ and occurring on poorly-drained or imperfectly-drained soils.

3. Wet rich woodland

FouRTH SoRT: Select all stands containing White Spruce with crown closure $\geq 40 \%$.

4. White Spruce woods

RESidual Stands:

5. "Disturbed forest"

Birch (Betula alleghaniensis) had a somewhat wider distribution, also occurring at a rather high level at wet rich woodland sampling points. In the initial trial sortings all stands containing any presence of Sugar Maple, American Beech and Yellow Birch were selected; however, for the final sorting it was decided to exclude those stands selected due to the presence of Yellow Birch that occurred on poorly-drained, imperfectly-drained or organic soils, soils more characteristic of wet rich woodland than of upland hardwood forest. Also, in the final sort, Eastern Hemlock (Tsuga canadensis) was included as a selecting species, and stands containing American Elm (Ulmus americana), Eastern White Cedar (Thuja occidentalis) and White Ash (Fraxinus americana), all characteristic of wet rich woodland, were specifically excluded.

2. Black Spruce forest. The problem in segregating stands of this forest-type was choosing a minimum percentage crown closure for Black Spruce. Since the mean percentage woody biomass contribution of Black Spruce at the Black Spruce forest sampling points was $53.1 \%$ (Sobey and Glen 2002), it was decided to set both a high value and also one that made ecological sense: the criterion used in the final sort was that for a stand to be assigned to Black Spruce forest, at least $50 \%$ of its canopy had to be Black Spruce. From the earlier trial sortings it had also become evident that it was necessary to exclude any stands containing American Elm, White Ash or Eastern White Cedar, species virtually absent from this forest-type.

3. Wet rich woodland. In the early trial sortings an attempt was made to select stands of this forest-type on the percentage crown closure of its most important tree species: Red Maple (Acer rubrum) - a minimum crown closure of $\geq 25 \%$ was set. However, the problem was that Red Maple was also present at high levels in the still unsorted "disturbed conifer-dominated forest". It was thus decided to make use of the fact that $80.2 \%$ of the sampling points of the TWINSPAN wet rich woodland occurred on imperfectly- and poorly-drained soil series (Sobey and Glen 2002). In the end the criterion used was firstly to select all stands containing the minor tree species diagnostic of this forest-type (as evident in the TWINSPAN classification): i.e., White Ash, American Elm and EasternWhite Cedar, as well as all stands classified as "swampy" by the photo-interpreters. Then, since an overall factor distinguishing the TWINSPAN wet rich woodland sampling points from the disturbed conifer-dominated forest was a higher level of total hardwoods (Sobey and Glen 2002), we selected all stands with a minimum total hardwood crown closure of $50 \%$, in combination with a requirement that all such stands be on poorly- and imperfectly-drained soils.

Having selected the stands that appear to be derived from pre-European settlement forest-types, the next step was to separate the remaining stands into the two types of successional and disturbed forest: i.e., White Spruce woods and disturbed conifer-dominated forest.

4. White Spruce woods. Here it was a matter of selecting the minimum percentage crown closure of White Spruce for a stand to be assigned to White Spruce woods. Given the fact that the mean percentage contribution of White Spruce to the woody biomass of TWINSPAN White Spruce woods sampling points was $62.2 \%$ and in the disturbed conifer-dominated forest it was $16.7 \%$ (Sobey and Glen 2002), a middle level (40\%) was chosen.

5. Disturbed conifer-dominated forest (or simply "disturbed forest"). The residual stands should by default correspond to the remaining TWINSPAN forest-type (disturbed conifer-dominated forest), even if 
TABLE 2. The number of hectares and stands (also as percentages) assigned to each stand-type in the computer-sorting. A percentage breakdown of the stand area by drainage class is also given, as is its status in 1935 as either forest-covered or cleared land as determined from a 1935 aerial photographic survey of the whole island. (In brackets after the forested percentage is the equivalent parameter for the TwINSPAN forest-type sampling points of the 1991 field survey - those bolded are within $\pm 20 \%$ of the stand value.)

\begin{tabular}{|c|c|c|c|c|c|c|}
\hline & \multicolumn{5}{|c|}{ STAND-TyPES } & \multirow[b]{2}{*}{ TOTALS } \\
\hline & $\begin{array}{c}\text { Upland } \\
\text { Hardwood } \\
\text { Forest }\end{array}$ & $\begin{array}{c}\text { Black } \\
\text { Spruce } \\
\text { Forest }\end{array}$ & $\begin{array}{l}\text { Wet Rich } \\
\text { Woodland }\end{array}$ & $\begin{array}{l}\text { White } \\
\text { Spruce } \\
\text { Woods }\end{array}$ & $\begin{array}{c}\text { Disturbed } \\
\text { Forest }\end{array}$ & \\
\hline HeCtARES & 55043 & 33106 & 42192 & 57982 & 65259 & 253582 \\
\hline Percentage of area & 21.7 & 13.1 & 16.6 & 22.9 & 25.7 & 100 \\
\hline NuMbER OF STANDS & 16170 & 8049 & 13863 & 22709 & 22166 & 82957 \\
\hline Percentage of stands & 19.5 & 9.7 & 16.7 & 27.4 & 26.7 & 100 \\
\hline \multicolumn{7}{|c|}{ Drainage Class ( $\%$ of area) } \\
\hline Organic & 0.04 & 6.8 & 0.78 & 0.58 & 0.86 & 1.4 \\
\hline Poorly-drained & 5.8 & 54.8 & 70.1 & 11.6 & 14.5 & 25.8 \\
\hline Imperfectly-drained & 3.9 & 16.8 & 24.6 & 8.1 & 7.8 & 10.7 \\
\hline Well-drained (medium) & 2.7 & 1.1 & 0.74 & 2.8 & 5.0 & 2.4 \\
\hline Well-drained (coarse) & 74.4 & 9.0 & 2.2 & 48.3 & 46.2 & 35.6 \\
\hline Rapidly-drained & 12.9 & 10.2 & 1.3 & 27.3 & 24.1 & 14.9 \\
\hline Unclassified & 0.28 & 1.3 & 0.18 & 1.2 & 1.5 & 0.93 \\
\hline \multicolumn{7}{|l|}{ STATUS in 1935 (\% of area) } \\
\hline Forested & $\begin{array}{c}93.8 \\
(\mathbf{8 6 . 4})\end{array}$ & $\begin{array}{c}77.2 \\
(\mathbf{6 7 . 5})\end{array}$ & $\begin{array}{c}75.8 \\
(\mathbf{7 9 . 5})\end{array}$ & $\begin{array}{c}37.6 \\
(24.4)\end{array}$ & $\begin{array}{c}67.4 \\
(\mathbf{7 4 . 2})\end{array}$ & $\begin{array}{c}69.0 \\
(69.5)\end{array}$ \\
\hline Cleared land & 6.2 & 22.8 & 24.2 & 62.4 & 32.6 & 31.0 \\
\hline
\end{tabular}

all are not in fact dominated by conifers. In the trial sortings an additional fifth sort was carried out in order to separate out the residual stands that were indeed conifer-dominated. This was done by sorting on a minimum conifer crown closure of $\geq 50 \%$ - this selected $42 \%$ of the residual stands. The other group was thus termed "disturbed hardwood-dominated forest", i.e., comprising residual stands with hardwoods > $50 \%$ crown closure. However, in the end, the distinction between hardwood and softwood domination in the residuals was not considered important and these stands have been simply termed "disturbed forest".

\section{Results}

Table 2 presents the results of the final computer sorting, expressed in terms of the area in hectares and the number of aerial stands assigned to each standtype, both also expressed as percentages. Table 2 also gives a breakdown of the soil drainage classes for each of the stand-types and their status in 1935 (as "cleared land" or "forested"), as determined from analysis of the earliest aerial photographic survey of the island (see Glen 1997). The tree species make-up of the five stand-types is shown in Table 3 and the computer-printed maps showing their distribution on the island are shown in Figures 3 to 7.

In the sorting, the 1990 "high forest" of the island was divided into five stand-types - see Appendix 1 for summary descriptions of each of these stand-types. These fall naturally into two groups, each of which occupies about half of the island's forested area: (1) the three stand-types which appear to be recognizable descendants (even if heavily-modified) of pre-European settlement forest-types (upland hardwood forest, Black Spruce forest and wet rich woodland) - these make up $51.4 \%$ of the area under high forest; (2) the two other stand-types (old field White Spruce woods and "disturbed forest"), representing more disturbed and/or successional types not likely to have been important in the pre-European forest - these make up the other $48.6 \%$. It is likely that before the period of European settlement, land surfaces now under these two latter stand-types would have been covered by one of the three "primary" stand-types.

\section{Evaluating the validity of the stand-types}

One way of assessing the validity of the products of the sorting is to compare, as in Table 3, the tree species composition of each stand-type (in the form of percentage crown closure) with the equivalent parameters of the corresponding TWINSPAN forest-type: the percentage contribution to woody biomass in the 1200 variable-radius plots of the ground survey, and the contribution of each of the tree species to the percentage crown closure in those stand polygons in which the 1200 variable-radius plots were located. Another way to assess the validity of the sorting is to compare the drainage properties and the status in 1935 of the aerial stand-types with those of the TWINSPAN-based foresttypes (Tables 2 and 4). The data required for these comparisons were extracted using the Database program "FoxPro" from the 1991 field survey database 
TABLE 3. The mean percentage crown closure ( \pm S.E.) of the principal tree species in each stand-type (based on all the stand-polygons of each stand-type including those in which the species was not recorded). To enable comparison of these values with the equivalent parameters for the TWINSPAN forest-types, placed below in round brackets is the mean percentage contribution $( \pm$ S.E. $)$ of each tree species to the total tree biomass in the variable-radius plots of the corresponding TwINSPAN forest-type; and in square brackets the mean percentage crown closure of the tree species $( \pm$ S.E.) in those standpolygons in which the variable-radius plots were located. For crown closure values (unbracketed) $>10 \%$, a bolded percentage within the brackets indicates that there is "good agreement" between the two values (i.e., the bracketed value lies within $\pm 20 \%$ of the unbracketed value), while an italicized bolded percentage indicates a "notable discrepancy" between the two values (i.e., the bracketed value is $> \pm 50 \%$ of the unbracketed value); where crown closures (unbracketed) were $<10 \%$, the differences were assessed subjectively on the basis of their relative magnitudes.

\begin{tabular}{|c|c|c|c|c|c|c|}
\hline & \multicolumn{5}{|c|}{ Stand-Types } & \multirow{2}{*}{$\begin{array}{c}\text { ALL STANDS } \\
\text { (All } 1200 \text { plots } \dagger) \\
\text { [All } 1200 \text { sampling } \\
\text { point stands] }\end{array}$} \\
\hline & $\begin{array}{l}\text { Upland } \\
\text { Hardwood } \\
\text { Forest }\end{array}$ & $\begin{array}{l}\text { Black } \\
\text { Spruce } \\
\text { Forest }\end{array}$ & $\begin{array}{c}\text { Wet } \\
\text { Rich } \\
\text { Woodland }\end{array}$ & $\begin{array}{l}\text { White } \\
\text { Spruce } \\
\text { Woods }\end{array}$ & $\begin{array}{c}\text { Disturbed [ } \\
\text { Forest }\end{array}$ & \\
\hline \multicolumn{7}{|l|}{ CONIFERS: } \\
\hline Picea mariana & $\begin{array}{l}0.22 \pm 0.020 \\
(\mathbf{0 . 7 2} \pm \mathbf{0 . 3 5}) \\
{[\mathbf{0 . 7 9} \pm \mathbf{0 . 2 8}]}\end{array}$ & $\begin{array}{l}71.4 \pm 0.18 \\
(53.1 \pm 4.9) \\
{[39.6 \pm 3.8]}\end{array}$ & $\begin{array}{c}9.9 \pm 0.13 \\
(3.8 \pm 1.2) \\
{[\mathbf{1 3 . 3} \pm \mathbf{1 . 7}]}\end{array}$ & $\begin{array}{l}1.1 \pm 0.034 \\
(4.3 \pm 1.5) \\
{[4.1 \pm 1.1]}\end{array}$ & $\begin{array}{l}5.3 \pm 0.079 \\
(10.1 \pm 1.4) \\
{[12.4 \pm 1.3]}\end{array}$ & $\begin{array}{c}10.4 \pm 0.080 \\
(5.4 \pm 0.57) \\
{[\mathbf{9 . 1} \pm \mathbf{0 . 5 9}]}\end{array}$ \\
\hline Picea rubens & $\begin{array}{l}0.59 \pm 0.032 \\
(\mathbf{0 . 8 8} \pm \mathbf{0 . 2 7}) \\
{[\mathbf{0 . 9 8} \pm \mathbf{0 . 2 8}]}\end{array}$ & $\begin{array}{c}0.69 \pm 0.042 \\
(\mathbf{1 7 . 3} \pm \mathbf{3 . 8}) \\
{[3.3 \pm 1.2]}\end{array}$ & $\begin{array}{c}2.9 \pm 0.072 \\
(0.51 \pm 0.30) \\
{[5.4 \pm 1.1]}\end{array}$ & $\begin{array}{c}0.47 \pm 0.021 \\
(4.6 \pm 1.2) \\
{[3.0 \pm 1.1]}\end{array}$ & $\begin{array}{c}7.1 \pm 0.096 \\
(7.1 \pm \mathbf{1 . 2}) \\
{[3.6 \pm 0.66]}\end{array}$ & $\begin{array}{l}2.7 \pm 0.036 \\
(\mathbf{2 . 8} \pm \mathbf{0 . 3 2}) \\
{[\mathbf{2 . 6} \pm \mathbf{0 . 2 8}]}\end{array}$ \\
\hline Picea glauca & $\begin{array}{c}4.8 \pm 0.086 \\
(8.6 \pm 0.92) \\
{[10.3 \pm 0.94]}\end{array}$ & $\begin{array}{c}1.6 \pm 0.068 \\
(7.2 \pm 2.3) \\
{[25.1 \pm 3.4]}\end{array}$ & $\begin{array}{c}8.2 \pm 0.11 \\
(\mathbf{1 8 . 0} \pm 2.2) \\
{[7.3 \pm \mathbf{0 . 9 8}]}\end{array}$ & $\begin{array}{l}68.1 \pm 0.13 \\
(62.2 \pm 3.4) \\
{[47.9 \pm 3.0]}\end{array}$ & $\begin{array}{c}10.4 \pm 0.078 \\
(16.7 \pm 1.5) \\
{[17.1 \pm 1.3]}\end{array}$ & $\begin{array}{c}24.2 \pm 0.11 \\
(17.0 \pm 1.0) \\
{[17.5 \pm 0.76]}\end{array}$ \\
\hline Abies balsamea & $\begin{array}{c}9.0 \pm 0.093 \\
(\mathbf{1 8 . 9} \pm \mathbf{1 . 2}) \\
{[\mathbf{1 0 . 2} \pm \mathbf{0 . 6 0}]}\end{array}$ & $\begin{array}{c}4.8 \pm 0.086 \\
(\mathbf{6 . 9} \pm \mathbf{1 . 9}) \\
{[7.3 \pm 1.2]}\end{array}$ & $\begin{array}{c}5.6 \pm 0.072 \\
(\mathbf{1 3 . 5} \pm \mathbf{1 . 5}) \\
{[\mathbf{7 . 8} \pm \mathbf{1 . 0}]}\end{array}$ & $\begin{array}{c}3.8 \pm 0.053 \\
(8.4 \pm \mathbf{1 . 7}) \\
{[\mathbf{5 . 6} \pm \mathbf{0 . 7 7}]}\end{array}$ & $\begin{array}{c}9.0 \pm 0.089 \\
(\mathbf{2 4 . 9} \pm \mathbf{1 . 6}) \\
{[\mathbf{1 1 . 1} \pm \mathbf{0 . 6 7}]}\end{array}$ & $\begin{array}{c}6.6 \pm 0.037 \\
(17.6 \pm 0.75) \\
{[8.9 \pm \mathbf{0 . 3 3}]}\end{array}$ \\
\hline Tsuga canadensis & $\begin{array}{c}0.12 \pm 0.012 \\
(0.32 \pm 0.16) \\
{[0]}\end{array}$ & $\begin{array}{l}0 \\
(0) \\
{[0]}\end{array}$ & $\begin{array}{c}0 \\
(0) \\
{[0]}\end{array}$ & $\begin{array}{c}0 \\
(0.81 \pm 0.54) \\
{[0]}\end{array}$ & $\begin{array}{c}0 \\
(0.42 \pm 0.25) \\
{[0]}\end{array}$ & $\begin{array}{c}0.023 \pm 0.0023 \\
(\mathbf{0 . 4 0} \pm \mathbf{0 . 1 4}) \\
{[0]}\end{array}$ \\
\hline Larix laricina & $\begin{array}{c}0.082 \pm 0.0097 \\
(\mathbf{0 . 4 8} \pm \mathbf{0 . 1 8}) \\
{[1.5 \pm 0.35]}\end{array}$ & $\begin{array}{l}8.5 \pm 0.11 \\
(\mathbf{9 . 0} \pm \mathbf{2 . 1}) \\
{[\mathbf{9 . 5} \pm \mathbf{1 . 5}]}\end{array}$ & $\begin{array}{c}5.4 \pm 0.075 \\
(\mathbf{7 . 3} \pm \mathbf{1 . 7}) \\
{[\mathbf{7 . 8} \pm \mathbf{1 . 2}]}\end{array}$ & $\begin{array}{c}6.0 \pm 0.075 \\
(3.7 \pm 0.84) \\
{[\mathbf{8 . 8} \pm \mathbf{1 . 6}]}\end{array}$ & $\begin{array}{c}12.8 \pm 0.16 \\
(3.8 \pm \mathbf{0 . 6 9}) \\
{[\mathbf{7 . 6} \pm \mathbf{0 . 8 1}]}\end{array}$ & $\begin{array}{l}7.1 \pm 0.052 \\
(2.6 \pm 0.31) \\
{[\mathbf{5 . 3} \pm \mathbf{0 . 3 7}]}\end{array}$ \\
\hline Thuja occidentalis & $\begin{array}{c}0 \\
(0.42 \pm 0.25) \\
{[0.023 \pm-]}\end{array}$ & $\begin{array}{c}0 \\
(0.12 \pm 0.13) \\
{[0]}\end{array}$ & $\begin{array}{c}1.2 \pm 0.037 \\
(7.1 \pm 1.7) \\
{[0.38 \pm-]}\end{array}$ & $\begin{array}{c}0 \\
(0) \\
{[0.15 \pm-]}\end{array}$ & $\begin{array}{c}0 \\
(0.64 \pm 0.32) \\
{[0.39 \pm 0.14]}\end{array}$ & $\begin{array}{c}0.20 \pm 0.0064 \\
(0.93 \pm 0.23) \\
{[\mathbf{0 . 1 7} \pm \mathbf{0 . 0 4 1}]}\end{array}$ \\
\hline TOTAL CONIFERS & $\begin{array}{c}14.9 \\
(30.4) \\
{[23.8]}\end{array}$ & $\begin{array}{c}87.3 \\
(94.4) \\
{[84.7]}\end{array}$ & $\begin{array}{c}34.9 \\
(50.0) \\
{[42.0]}\end{array}$ & $\begin{array}{c}80.4 \\
(\mathbf{8 4 . 1}) \\
{[\mathbf{6 9 . 6}]} \\
\end{array}$ & $\begin{array}{c}46.3 \\
(64.5) \\
{[\mathbf{5 2 . 4}]}\end{array}$ & $\begin{array}{c}51.4 \\
(\mathbf{4 7 . 3}) \\
{[\mathbf{4 4 . 4}]}\end{array}$ \\
\hline \multicolumn{7}{|l|}{ BROAD-LEAVES: } \\
\hline Acer rubrum & $\begin{array}{c}35.7 \pm 0.11 \\
(\mathbf{3 3 . 3} \pm \mathbf{1 . 4}) \\
{[\mathbf{3 0 . 4} \pm \mathbf{0 . 7 3}]}\end{array}$ & $\begin{array}{c}4.8 \pm 0.086 \\
(\mathbf{2 . 5} \pm \mathbf{0 . 7 7}) \\
{[\mathbf{5 . 1} \pm \mathbf{1 . 1}]}\end{array}$ & $\begin{array}{l}25.7 \pm 0.13 \\
(\mathbf{2 4 . 6} \pm \mathbf{2 . 4}) \\
{[\mathbf{2 6 . 3} \pm \mathbf{1 . 5}]}\end{array}$ & $\begin{array}{c}5.4 \pm 0.061 \\
(\mathbf{4 . 6} \pm \mathbf{1 . 1}) \\
{[8.3 \pm \mathbf{1 . 1}]}\end{array}$ & $\begin{array}{c}20.1 \pm 0.12 \\
(\mathbf{1 9 . 0} \pm \mathbf{1 . 5}) \\
{[\mathbf{1 8 . 9} \pm \mathbf{0 . 9 2}]}\end{array}$ & $\begin{array}{c}18.7 \pm 0.063 \\
(25.1 \pm 1.2) \\
{[\mathbf{2 1 . 7} \pm \mathbf{0 . 5 2}]}\end{array}$ \\
\hline Acer saccharum & $\begin{array}{c}21.6 \pm 0.10 \\
(9.7 \pm 0.89) \\
{[16.7 \pm 0.76]}\end{array}$ & $\begin{array}{c}0 \\
(0) \\
{[0.5 \pm-]}\end{array}$ & $\begin{array}{c}0.45 \pm 0.030 \\
(1.7 \pm 0.56) \\
{[2.1 \pm 0.55]}\end{array}$ & $\begin{array}{c}0 \\
(0.59 \pm 0.46) \\
{[2.1 \pm 0.60]}\end{array}$ & $\begin{array}{c}0 \\
(0.28 \pm 0.13) \\
{[3.5 \pm 0.53]}\end{array}$ & $\begin{array}{l}4.3 \pm 0.036 \\
(\mathbf{4 . 9} \pm \mathbf{0 . 5 4}) \\
{[7.7 \pm 0.38]}\end{array}$ \\
\hline Betula alleghaniensis & $\begin{array}{c}7.8 \pm 0.070 \\
(\mathbf{5 . 6} \pm \mathbf{0 . 6 2}) \\
{[\mathbf{6 . 7} \pm \mathbf{0 . 4 1}]}\end{array}$ & $\begin{array}{l}0 \\
(0) \\
{[0]}\end{array}$ & $\begin{array}{c}0.22 \pm 0.016 \\
(3.3 \pm 0.84) \\
{[0.71 \pm 0.22]}\end{array}$ & $\begin{array}{c}0.013 \pm 0.0026 \\
(0.22 \pm 0.13) \\
{[1.0 \pm 0.35]}\end{array}$ & $\begin{array}{c}0.090 \pm 0.0024 \\
(1.4 \pm 0.40) \\
{[0.92 \pm 0.23]}\end{array}$ & $\begin{array}{c}1.6 \pm 0.017 \\
(3.9 \pm 0.39) \\
{[3.0 \pm 0.19]}\end{array}$ \\
\hline Betula papyrifera & $\begin{array}{c}13.7 \pm 0.087 \\
(9.2 \pm 0.74) \\
{[\mathbf{1 3 . 1} \pm \mathbf{0 . 5 3}]}\end{array}$ & $\begin{array}{c}2.5 \pm 0.059 \\
(0.63 \pm 0.36) \\
{[2.5 \pm \mathbf{0 . 6 5}]}\end{array}$ & $\begin{array}{c}12.7 \pm 0.089 \\
(\mathbf{5 . 6} \pm \mathbf{0 . 9 4}) \\
{[\mathbf{1 1 . 9} \pm \mathbf{0 . 9 7}]}\end{array}$ & $\begin{array}{l}6.3 \pm 0.059 \\
(3.6 \pm 0.78) \\
{[\mathbf{6 . 9} \pm \mathbf{0 . 8 5}]}\end{array}$ & $\begin{array}{c}13.4 \pm 0.088 \\
(\mathbf{4 . 1} \pm \mathbf{0 . 6 0}) \\
{[\mathbf{1 1 . 4} \pm \mathbf{0 . 6 6}]}\end{array}$ & $\begin{array}{c}10.3 \pm 0.039 \\
(7.3 \pm 0.50) \\
{[\mathbf{1 0 . 8} \pm \mathbf{0 . 3 3}]}\end{array}$ \\
\hline Fagus grandifolia & $\begin{array}{l}1.5 \pm 0.036 \\
(4.1 \pm 0.58) \\
{[\mathbf{1 . 1} \pm \mathbf{0 . 1 9}]}\end{array}$ & $\begin{array}{l}0 \\
(0) \\
{[0]}\end{array}$ & $\begin{array}{c}0.017 \pm 0.0044 \\
(0) \\
{[0.19 \pm-]}\end{array}$ & $\begin{array}{c}0 \\
(0.37 \pm 0.24) \\
{[0.074 \pm-]}\end{array}$ & $\begin{array}{c}0 \\
(0.23 \pm 0.11) \\
{[0.21 \pm 0.10]}\end{array}$ & $\begin{array}{c}0.30 \pm 0.0073 \\
(2.7 \pm 0.37) \\
{[\mathbf{0 . 4 9} \pm \mathbf{0 . 0 7 4}]}\end{array}$ \\
\hline
\end{tabular}


TABLE 3. (continued from previous page)

\begin{tabular}{|c|c|c|c|c|c|c|}
\hline & \multicolumn{5}{|c|}{ STAND-TyPES } & \multirow{2}{*}{$\begin{array}{c}\text { ALL STANDS } \\
\text { (All 1200 plots } \dagger \text { ) } \\
\text { [All } 1200 \text { sampling } \\
\text { point stands] }\end{array}$} \\
\hline & $\begin{array}{l}\text { Upland } \\
\text { Hardwood } \\
\text { Forest }\end{array}$ & $\begin{array}{l}\text { Black } \\
\text { Spruce } \\
\text { Forest }\end{array}$ & $\begin{array}{c}\text { Wet } \\
\text { Rich } \\
\text { Woodland }\end{array}$ & $\begin{array}{l}\text { White } \\
\text { Spruce } \\
\text { Woods }\end{array}$ & $\begin{array}{l}\text { "Disturbed } \\
\text { Forest"" }\end{array}$ & \\
\hline Populus spp. $\ddagger$ & $\begin{array}{l}4.6 \pm 0.075 \\
(\mathbf{4 . 1} \pm \mathbf{0 . 6 5}) \\
{[\mathbf{6 . 9} \pm \mathbf{0 . 5 3}]}\end{array}$ & $\begin{array}{c}5.0 \pm 0.090 \\
(1.1 \pm 1.0) \\
{[6.8 \pm 1.2]}\end{array}$ & $\begin{array}{c}21.4 \pm 0.15 \\
(7.8 \pm 1.6) \\
{[11.2 \pm 1.0]}\end{array}$ & $\begin{array}{c}7.6 \pm 0.070 \\
(4.7 \pm 1.2) \\
{[\mathbf{1 0 . 7} \pm \mathbf{1 . 1}]}\end{array}$ & $\begin{array}{c}18.8 \pm 0.14 \\
(7.4 \pm \mathbf{1 . 1}) \\
{[10.9 \pm 0.80]}\end{array}$ & $\begin{array}{c}12.3 \pm 0.057 \\
(6.6 \pm 0.62) \\
{[9.6 \pm 0.39]}\end{array}$ \\
\hline Fraxinus americana & $\begin{array}{c}0 \\
(0.40 \pm 0.21) \\
{[0]}\end{array}$ & $\begin{array}{c}0 \\
(0) \\
{[0]}\end{array}$ & $\begin{array}{c}0.32 \pm 0.019 \\
(1.6 \pm 0.75) \\
{[0]}\end{array}$ & $\begin{array}{c}0 \\
(0) \\
{[0]}\end{array}$ & $\begin{array}{l}0 \\
(0) \\
{[0]}\end{array}$ & $\begin{array}{c}0.053 \pm 0.0031 \\
(\mathbf{0 . 4 6} \pm \mathbf{0 . 1 6}) \\
{[0]}\end{array}$ \\
\hline Ulmus americana & $\begin{array}{c}0 \\
(0.26 \pm 0.14) \\
{[0.47 \pm-]}\end{array}$ & $\begin{array}{c}0 \\
(0) \\
{[0]}\end{array}$ & $\begin{array}{c}0.84 \pm 0.035 \\
(3.2 \pm 1.1) \\
{[0.13 \pm-]}\end{array}$ & $\begin{array}{c}0 \\
(0) \\
{[0]}\end{array}$ & $\begin{array}{c}0 \\
(0) \\
{[0.035 \pm-]}\end{array}$ & $\begin{array}{c}0.14 \pm 0.0058 \\
(0.57 \pm 0.17) \\
{[0.042 \pm 0.019]}\end{array}$ \\
\hline Alnus incana & $\begin{array}{c}0.047 \pm 0.011 \\
(-) \\
{[0.16 \pm 0.12]}\end{array}$ & $\begin{array}{c}0.26 \pm 0.027 \\
(-) \\
{[0]}\end{array}$ & $\begin{array}{c}4.8 \pm 0.11 \\
(-) \\
{[\mathbf{4 . 0} \pm \mathbf{1 . 2}]}\end{array}$ & $\begin{array}{c}1.2 \pm 0.039 \\
(-) \\
{[\mathbf{1 . 1} \pm \mathbf{0 . 6 3}]}\end{array}$ & $\begin{array}{c}1.9 \pm 0.052 \\
(-) \\
{[0.85 \pm 0.38]}\end{array}$ & $\begin{array}{c}6.4 \pm 0.071 \\
(-) \\
{[1.1 \pm 0.22]}\end{array}$ \\
\hline \multirow[t]{2}{*}{$\begin{array}{l}\text { TOTAL BROAD-LEAVES } \\
\text { (excluding Alnus) }\end{array}$} & $\begin{array}{c}85.1 \\
(\mathbf{7 0 . 0})\end{array}$ & $\begin{array}{l}12.5 \\
(5.3)\end{array}$ & $\begin{array}{c}65.1 \\
(50.0)\end{array}$ & $\begin{array}{c}19.6 \\
(\mathbf{1 6 . 5})\end{array}$ & $\begin{array}{c}53.7 \\
(35.0)\end{array}$ & $\begin{array}{c}47.8 \\
(\mathbf{5 2 . 7})\end{array}$ \\
\hline & {$[75.6]$} & [14.9] & [56.7] & {$[30.3]$} & [46.9] & {$[55.6]$} \\
\hline Number of Stands & 16,170 & 8,049 & 13,863 & 22,709 & 22,166 & 82,957 \\
\hline
\end{tabular}

$\dagger$ For "all 1200 plots" the value in round brackets is the percentage contribution to the total above ground biomass (ovendry tonnes per hectare) in all 1200 variable-radius plots.

* Because it is impossible to distinguish the three native poplar species in aerial photographs (Populus tremuloides, $P$. balsamifera, $P$. grandidentata) they were grouped as "Populus spp." - however almost all of this is likely to have been P. tremuloides (Trembling Aspen).

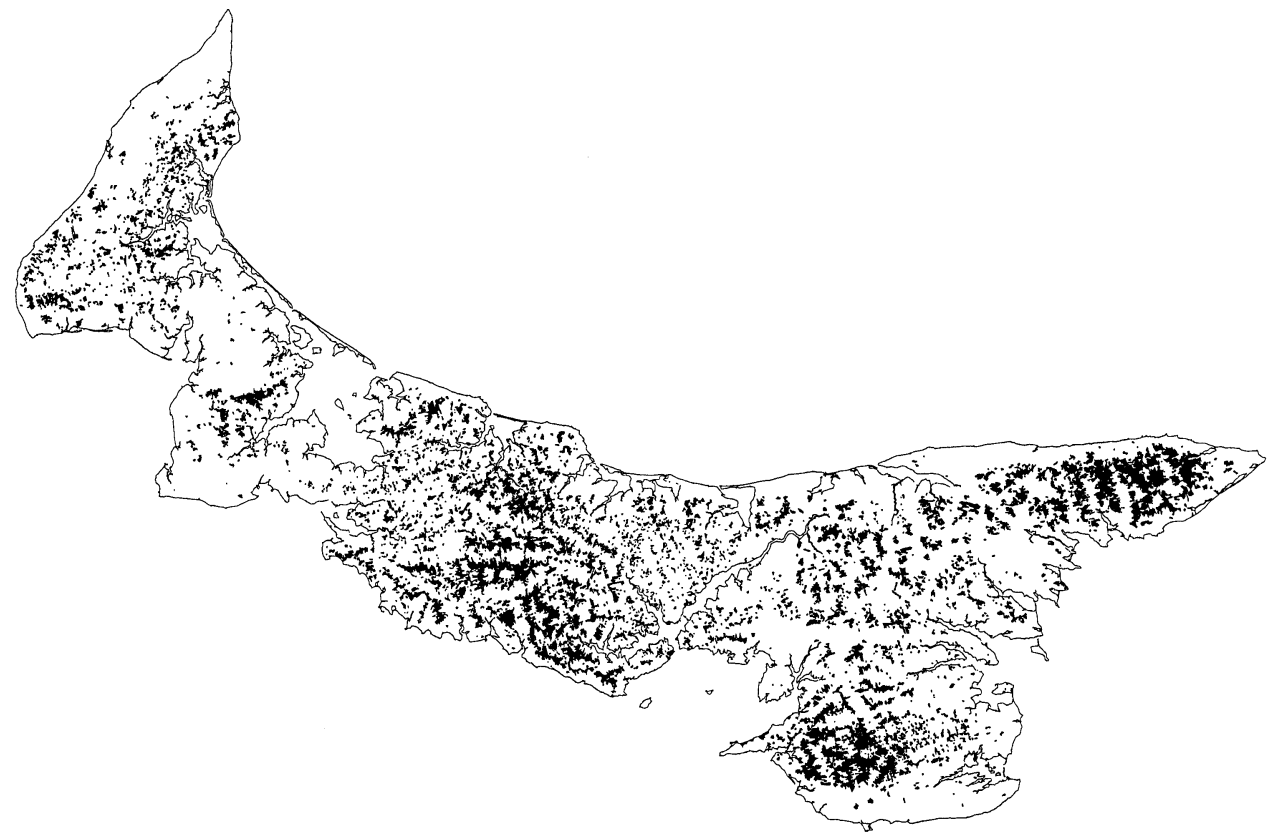

FIGURE 3. The distribution of stands of upland hardwood forest in 1990. 


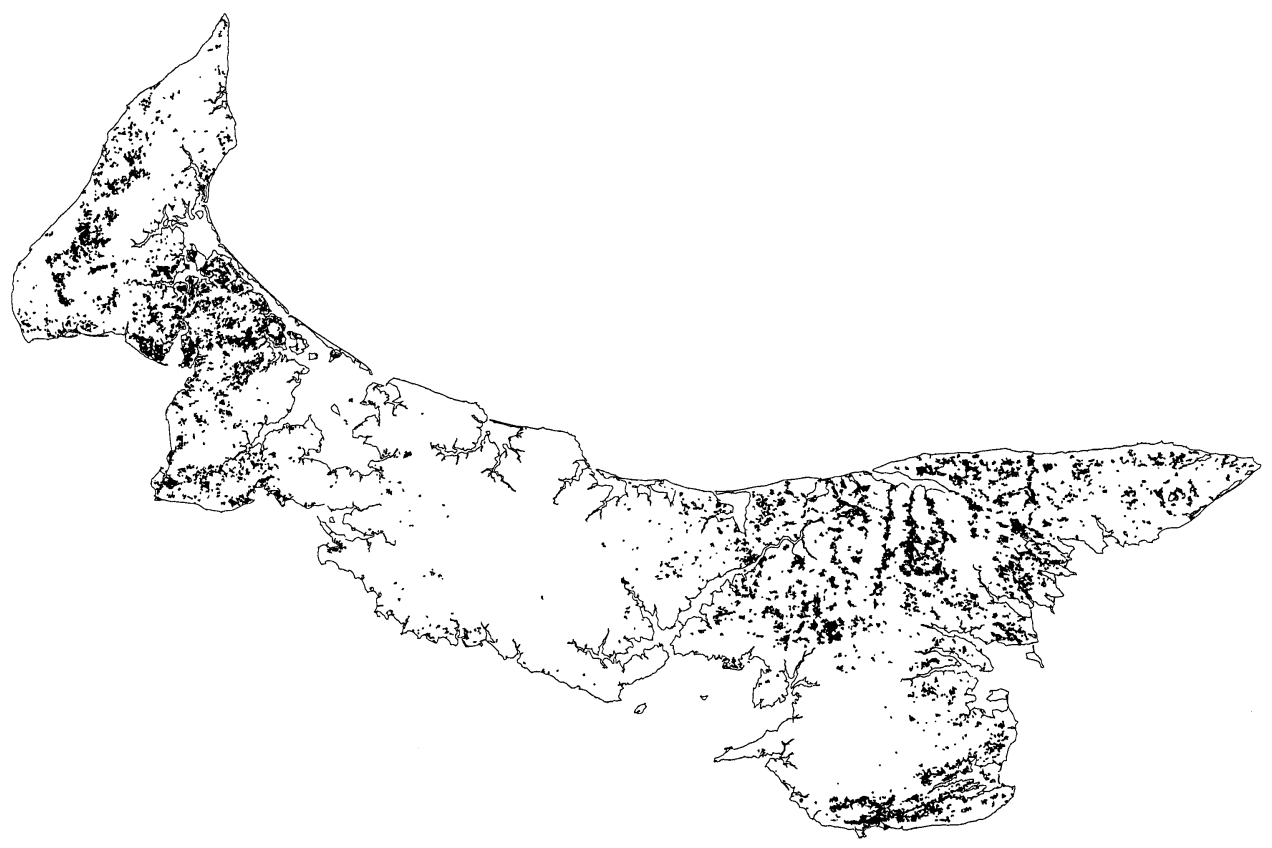

FIGURE 4. The distribution of stands of Black Spruce forest in 1990.

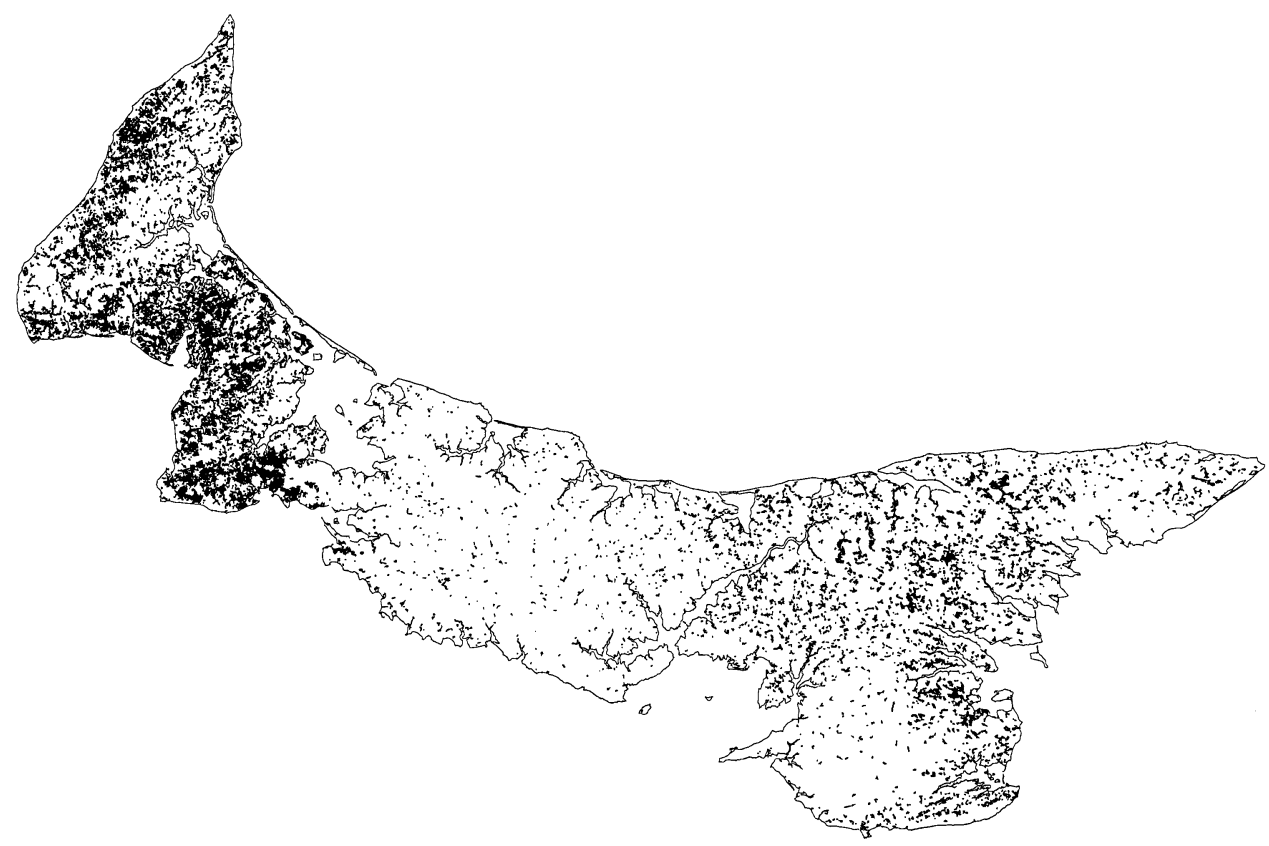

FIGURE 5. The distribution of stands of wet rich woodland in 1990. 


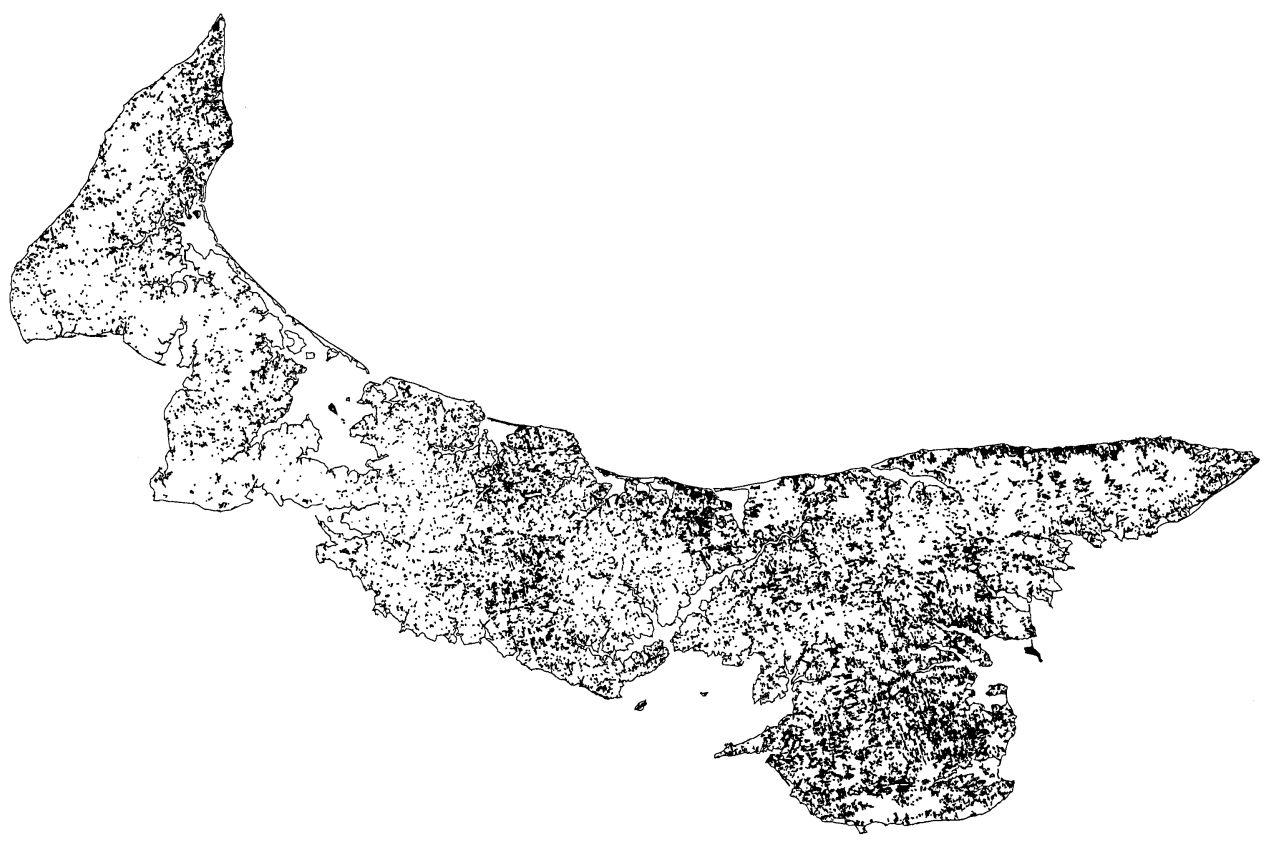

FIGURE 6. The distribution of stands of White Spruce woods in 1990.

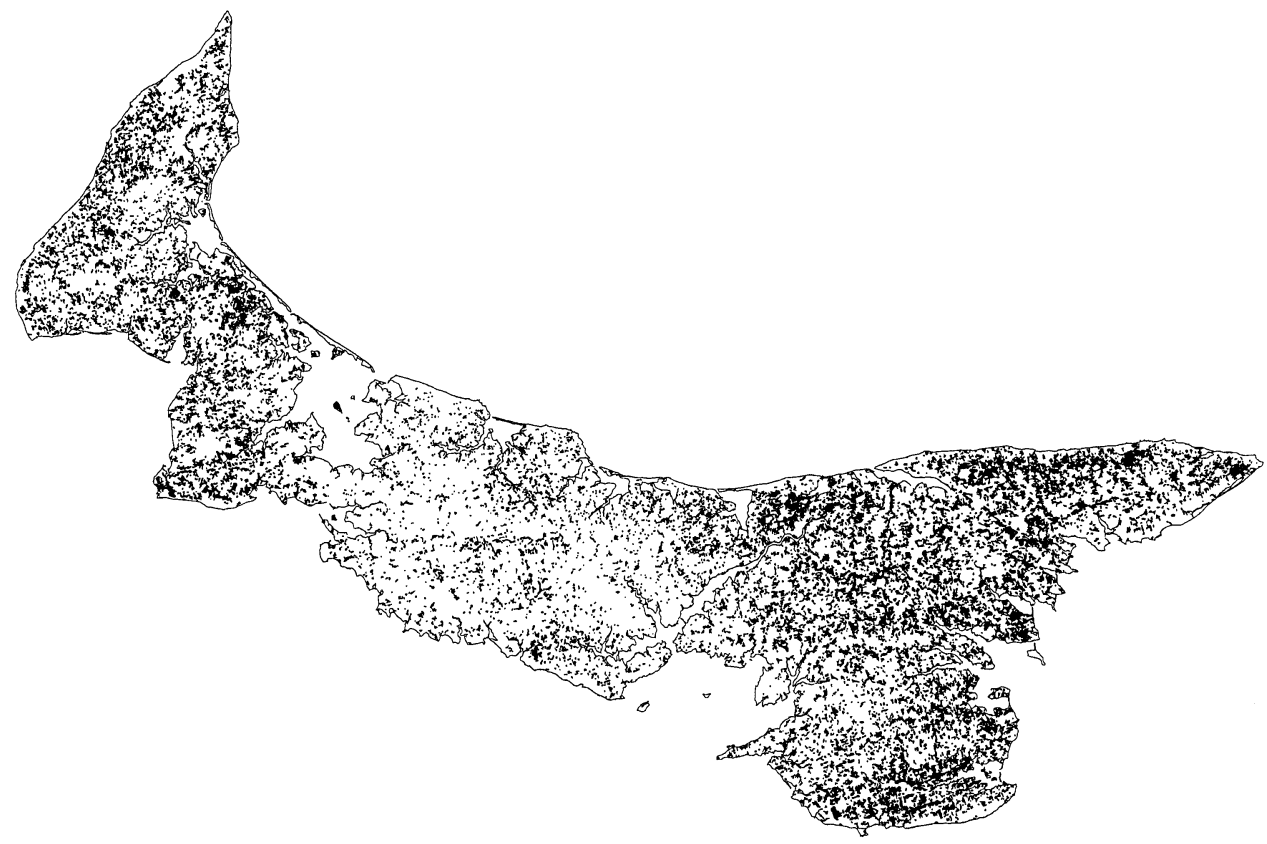

FIGURE 7. The distribution of stands of "disturbed forest" in 1990. 
TABLE 4. The soil drainage classes of the stand-types (derived from the 1:10 000 soil series maps of MacDougall et al. (1988)) expressed as the percentage of the stand-type's total area in each drainage class, ignoring the area of unclassified drainage. These are compared with the drainage classes of the corresponding TwINSPAN forest-types: (1) (in round brackets) the soil drainage class at the sampling points of the 1991 field survey as determined from soil pits, and (2) [in square brackets] the drainage class of those soil series polygons in which the sampling points were located, derived also from MacDougall et al. (1988), both values being expressed as the percentage of the total area or of the sampling points in each drainage class. *

\begin{tabular}{|c|c|c|c|c|c|c|}
\hline \multirow[b]{2}{*}{ Soll Drainage Class } & \multicolumn{5}{|c|}{ STAND-TyPES } & \multirow[b]{2}{*}{$\begin{array}{c}\text { ALL } \\
\text { STANDS } \\
\text { (or points) }\end{array}$} \\
\hline & $\begin{array}{l}\text { Upland } \\
\text { Hardwood } \\
\text { Forest }\end{array}$ & $\begin{array}{l}\text { Black } \\
\text { Spruce } \\
\text { Forest }\end{array}$ & $\begin{array}{l}\text { Wet Rich } \\
\text { Woodland }\end{array}$ & $\begin{array}{l}\text { White } \\
\text { Spruce } \\
\text { Woods }\end{array}$ & $\begin{array}{l}\text { "Disturbed } \\
\text { Forest" }\end{array}$ & \\
\hline $\begin{array}{l}\text { Poorly- and imperfectly- } \\
\text { drained soils (+ organic) }(\%)\end{array}$ & $\begin{array}{c}9.8 \\
(1.9) \\
{[12.9}\end{array}$ & $\begin{array}{c}79.4 \\
(\mathbf{6 6 . 3}) \\
{[73.8]}\end{array}$ & $\begin{array}{c}95.7 \\
(58.3) \\
{[\mathbf{8 0 . 3}}\end{array}$ & $\begin{array}{l}20.6 \\
(\mathbf{1 . 5}) \\
{[14.0]}\end{array}$ & $\begin{array}{l}23.6 \\
(15.9) \\
{[37.5]}\end{array}$ & $\begin{array}{c}39.2 \\
(\mathbf{1 8 . 4}) \\
{[33.6}\end{array}$ \\
\hline $\begin{array}{l}\text { Well- and rapidly- } \\
\text { drained soils (\%) }\end{array}$ & $\begin{array}{c}90.2 \\
(\mathbf{9 8 . 1}) \\
{[\mathbf{8 7 . 1}]}\end{array}$ & $\begin{array}{c}20.6 \\
(33.8) \\
{[26.3]}\end{array}$ & $\begin{array}{c}4.3 \\
(41.6) \\
{[19.9]}\end{array}$ & $\begin{array}{c}79.4 \\
(98.5) \\
{[\mathbf{8 5 . 9}]}\end{array}$ & $\begin{array}{c}76.4 \\
(\mathbf{8 4 . 1}) \\
{[\mathbf{6 2 . 5}]}\end{array}$ & $\begin{array}{c}60.8 \\
(81.6) \\
{[\mathbf{6 6 . 4}]}\end{array}$ \\
\hline
\end{tabular}

*For the meaning of the bolding and italicizing see the caption of Table 3.

and the 1990 aerial stand database, and then linked to the "MapInfo" G.I.S. for the province.

\section{(1) Comparing the composition of the tree canopy}

To facilitate the overall interpretation of the many comparisons being made, indices were selected for assessing the closeness of the two values: if the equivalent parameter for the TWINSPAN-based forest-type lay within $\pm 20 \%$ of the aerial-stand value, this was taken to indicate "good agreement" between the two values, whereas if the parameter was greater than $\pm 50 \%$ of the aerial-stand value this was considered a "notable discrepancy". On the basis of these criteria, it is evident that in overall terms there is a reasonably good fit between the mean tree canopy composition of the stand-types based on all of the stand polygons (Table 3 ), and the canopy composition of those stand polygons that contained the 1200 variable-radius plots: there are 29 "good agreements" and only two "notable discrepancies" for the crown closure of individual species. However, when the mean tree canopy composition for all of the stand polygons is compared with the percentage contribution to woody biomass in the variableradius plots, the match is not as good: here there were 15 "good agreements" and 17 "notable discrepancies". This greater level of discrepancy is not surprising considering that this latter comparison is between plots of different size (i.e., forest stands of variable size, but measured mostly in hectares (the mean stand area was about 3 hectares) and variable-radius plots with a mean size of about $100 \mathrm{~m}^{2}$ ), as well as different parameters (percentage crown closure as determined from an aerial photograph, with the percentage contribution to woody biomass based on the trunk diameter of the trees within the variable-radius plots).

Also relevant here is the greater difficulty in identifying tree species from an aerial photograph compared with the examination of actual specimens in a field survey. The photo-identification was based on such characters as texture, shape, colour and site (e.g., whether on upland or lowland). The conifers in particular presented problems: Balsam Fir (Abies balsamea) when present as an understorey species may not be apparent from the air; the three spruce species were frequently identified from their site: i.e., if in upland forest, it was listed as Red Spruce (Picea rubens), in lowland, Black Spruce, and on old-field sites, White Spruce, but this was not an infallible approach. Thus the photoidentification was not $100 \%$ accurate: the standard required for the 1990 aerial survey, confirmed by ground checks, was that at least $70 \%$ of the species-cover identification in a stand be correct for at least $90 \%$ of the time. Bearing these points in mind we observe the following:

Upland hardwood stands. In almost all of the comparisons (Table 3 ) there is generally a good correspondence between the parameters of the aerial stand-type and those of the TWINSPAN-defined forest-type.

Black Spruce stands. There are problems with the spruces (perhaps due to the problem in identifying the spruces, discussed above): in Table 3 the most notable discrepancy is the very low Red Spruce contribution to the aerial stand-type $(<1 \%)$ compared with its level in the variable-radius plots (17\%). Also evident is the fact that Black Spruce is at a somewhat higher level in the aerial stand-type (71\%) compared with either of the values for the TWINSPAN-defined forest-type. This is presumably due to the high crown closure level (i.e., $50 \%$ ) that was set as the criterion for inclusion of Black Spruce stands in this group.

Wet rich woodland stands. The chief species, Red Maple, shows no difference in either of the comparisons 
(Tables 3). However, there are some discrepancies: the use of a sorting criterion of $\geq 50 \%$ hardwoods must be the reason for the higher overall hardwood contribution in the aerial stand-type compared with the TWINSPAN forest-type, as well as the higher individual contributions of Trembling Aspen (Populus tremuloides) and White Birch (Betula papyrifera), though there is no discrepancy for the latter species in the comparison of the crown closures. Concomitantly, the conifer contribution is less in the aerial stand-type than in the variable-radius plots, but again there is less discrepancy for the crown closure comparison.

White Spruce stands. In overall terms there is a good correspondence between the two classifications, with the main species, White Spruce, giving a reasonably good fit - this time the better fit is for the variableradius plot comparison (Table 3 ).

"Disturbed forest" stands. This residual group has a smaller total conifer component than the TWINSPAN "disturbed conifer-dominated forest" (this discrepancy is less evident in the comparison of the crown closures - Table 3), and this is reflected especially in the levels of Balsam Fir (for the variable-radius plot comparison only), and to a smaller degree, in White Spruce and Black Spruce. Oddly, Tamarack (Larix laricina) is considerably higher in the aerial stand-type than it is in the variable-radius plots. Concomitantly, the hardwoods (notably Trembling Aspen) are higher in the aerial stand-type, while there is no difference for the levels of Red Maple.

\section{(2) Comparing the soil drainage classes and the 1935} status

There is a reasonably good agreement between the aerial stand-types and the TWINSPAN forest-types in their drainage class breakdown (Table 4), especially for the drainage classes as determined from the soil series at the 1200 sampling points. There is less agreement with the drainage classes as determined from the soil pits dug at the sampling points during the field inventory. The one showing the least correspondence is the wet rich woodland which has higher levels of poorly- and imperfectly-drained soils in the aerial stands, due to the direct use of these drainage classes as a sorting criterion. The status of the stands and sampling points in 1935 (i.e., whether they were forested or cleared land at that time) is in broad agreement for most of the forest-types (Table 2), with the greatest discrepancy being for the White Spruce woods.

\section{Discussion}

The TWINSPAN analysis of the 1991 field survey data (Sobey and Glen 2002) indicated the presence of five main forest-types on Prince Edward Island, three of these showing a relationship with pre-European settlement forest-types and two appearing to largely owe their presence to human influences. The objective of the current paper was the production of maps show- ing the total distribution of these five forest-types. This objective has been achieved, and for the first time ever we have fine-scale whole-island maps showing the distribution of the main forest-types. Furthermore, these maps have been produced using largely objective criteria and methods, and they are based on the actual forest present at a specific time (in the summer of 1990), with every mapped stand being locatable on the ground and thus potentially verifiable.

How valid are the maps as a picture of the distribution of the five forest-types on the island? Firstly, the maps appear to make ecological and geographical sense: the upland hardwood forest (Figure 3) occurs in areas of higher elevation (in island terms), and on soils having good drainage (Tables 2 and 4). In such areas the mapping indicates that it is present either as small woodlots surrounded by farmland, or as larger connected parcels (at the back end of farms) - especially in the central and south-eastern hill-lands, where steeper slopes and shallow soils placed restrictions on forest clearance in the past.

It is also evident that the Black Spruce forest and the wet rich woodland, which occur primarily on soils with poorer drainage (Tables 2 and 4), are segregated geographically from the upland hardwood forest. These predominate in areas of lower elevation, notably in parts of the east and west of the island (Figures 4 and 5). Though both of these forest-types occur in the same geographical areas, the TWINSPAN analysis indicated that they have very different ground and tree vegetation (Sobey and Glen 2002). They also have very different soil chemical properties - the wet rich woodland has soils that are comparatively base-rich and of higher $\mathrm{pH}$ with a lower $\mathrm{C} / \mathrm{N}$ (carbon-nitrogen) ratio, than the soils of Black Spruce forest, more acid and base-poor with a higher $\mathrm{C} / \mathrm{N}$ ratio. This dissimilarity was also evident from the fact that there was no overlap in their graphical distributions in the DECORANA ordination (Sobey and Glen 2002). Given their similar geographical distribution on the island, the question is whether in the mapping we have been able, using tree and soil criteria alone, to separate the stands of these two wet forest-types from each other. The differences in their tree composition parameters, evident in Table 3, suggest that we have.

Stands of the other two forest-types, the White Spruce woods and the disturbed forest, have a wider and more scattered distribution (Figures 6 and 7), occurring less as larger connected parcels, than as individual small stands, which is consistent with the fact that their occurrence is largely the product of human activity, which will tend to occur at a scale determined by the ownership of blocks of land. At the same time there is a geographical aspect to their distribution, with the White Spruce woods prevalent in the central hill-lands and in the eastern part of the island, its spatial distribution evidently determined by the geography of field and farm abandonment, while the disturbed forest is con- 
TABLE 5. For each soil drainage class, the total area (in hectares) under the three 'primary' forest stand-types in 1990, and the percentage of this area assigned in the computer-sorting to each stand-type is shown.

\begin{tabular}{lcccccc}
\hline \hline & \multicolumn{5}{c}{ DrainAGE Class } \\
\cline { 2 - 7 } PrimaRY ForEST & Organic & $\begin{array}{c}\text { Poorly- } \\
\text { Srained }\end{array}$ & $\begin{array}{c}\text { Imperfectly } \\
\text { drained }\end{array}$ & $\begin{array}{c}\text { Well-drained } \\
\text { (medium textured) }\end{array}$ & $\begin{array}{c}\text { Well-drained } \\
\text { (coarse textured) }\end{array}$ & Rapidly-drained \\
\hline Upland Hardwood Forest & 0.88 & 6.2 & 12.0 & 68.7 & 91.2 & 64.4 \\
Black Spruce Forest & 86.5 & 35.6 & 30.7 & 16.7 & 6.7 & 30.6 \\
Wet Rich Woodland & 12.6 & 58.2 & 57.3 & 14.6 & 2.1 & 5.0 \\
\hline Total Hectares & 2620 & 50912 & 18089 & 2137 & 465 & 11073 \\
\hline \hline
\end{tabular}

centrated largely in the far west and in the east of the island.

Although a significant and meaningful ecological picture has emerged from the sorting and mapping, at the same time it is important to point out some limitations: a basic one is that any sorting of forest stands into forest-types is a classification procedure, and any process of classification is a simplification. Compounding this was the fact that the stand sorting was reliant on the products of three other classification procedures: TWINSPAN, stand delineation (strictly-speaking not a classification procedure, but involving demarcation of the forest area into individual stands), and the soil series classification for the province. Each of these three prior procedures will have their own particular limitations.

It should also be pointed out that although three centuries of forest destruction and exploitation by Europeans have undoubtedly generalized and simplified the island's forest cover, the five maps are still a simplification of what was present in 1990. As noted in Sobey and Glen (2002) there are likely to have been other forest-types present but so uncommon as not to have been picked up in the 1991 field survey in sufficient quantity to be recognized as separate types (e.g., areas under Hemlock, White Pine, Eastern White Cedar and White Ash, now occurring as only a few small stands, but likely to have been more widespread in the past). Also, each of the five forest-types that has been recognized may have had sub-types that have been overlooked: e.g., the TWINSPAN classification subdivided the Black Spruce forest plots into wetter and dryer variants (Sobey 1995), but an attempt in the sorting to separate stands of these on their tree canopy composition was not successful. The upland hardwood may also have variants dominated by particular tree species. The only solution to this problem of both rare and more refined forest-types, is firstly to define them, and then to locate them on the ground and map them separately.

It should also be noted that the maps produced present a picture of the forest as it was at one particular time: in the summer of 1990 at the time of the aerial photographic survey. But the forests of Prince Edward Island, like forests the world over, are not fixed and static. Apart from natural factors, they are subject to the effects of continual human interference, for example, clear- and partial-cutting, forest clearance for agriculture, fire, and farm abandonment, as well as the natural successional processes resulting from these effects. On the other hand, although the three pre-European settlement woodland types may vary over time in the amount and proportion of the island's area that they occupy, we should not expect the general pattern of their distributions to change, related as this is to innate soil properties. However, the two successional foresttypes (White Spruce woods and disturbed forest) are likely to be only transitional on a site, and we may presume that given sufficient time, most of their sites would develop into one of the primary woodland types.

\section{Mapping the pre-European settlement forest of the} island

Despite the above limitations in the methodology, it is of interest to generalize the results even further by considering the potential for extending the mapping to areas without forest cover in 1990, incidentally, an aspect of all earlier attempts at mapping the province's forests (Stilgenbauer 1929; Halliday 1937; Rowe 1959; Loucks 1962). Such a mapping may have either of two objectives: (1) the reconstruction of the type of forest likely to have occurred before forest clearance, i.e., the "original-natural" forest sensu Peterken (1996); and/or (2) the prediction of the type of forest that would ultimately occur over the whole island if all areas were allowed to revert naturally to climax forest in the future; i.e., the "future-natural" forest sensu Peterken (1996). Either of these objectives involves trying to predict the climax forest-type on the land area now occupied by White Spruce woodland and the "disturbed forest", as well as the forest cover on land which in 1990 was clear of forest, i.e., the non-forested area evident in Figure 2, comprising some $43 \%$ of the island's land area (Anonymous 1992).

The easiest approach to such a mapping is to take advantage of the close relationship existing between natural vegetation and soils, by utilizing data derived from the comprehensive and fine-scale maps produced by the Prince Edward Island Soil Survey (MacDougall et al. 1988). We need first to examine any associations 


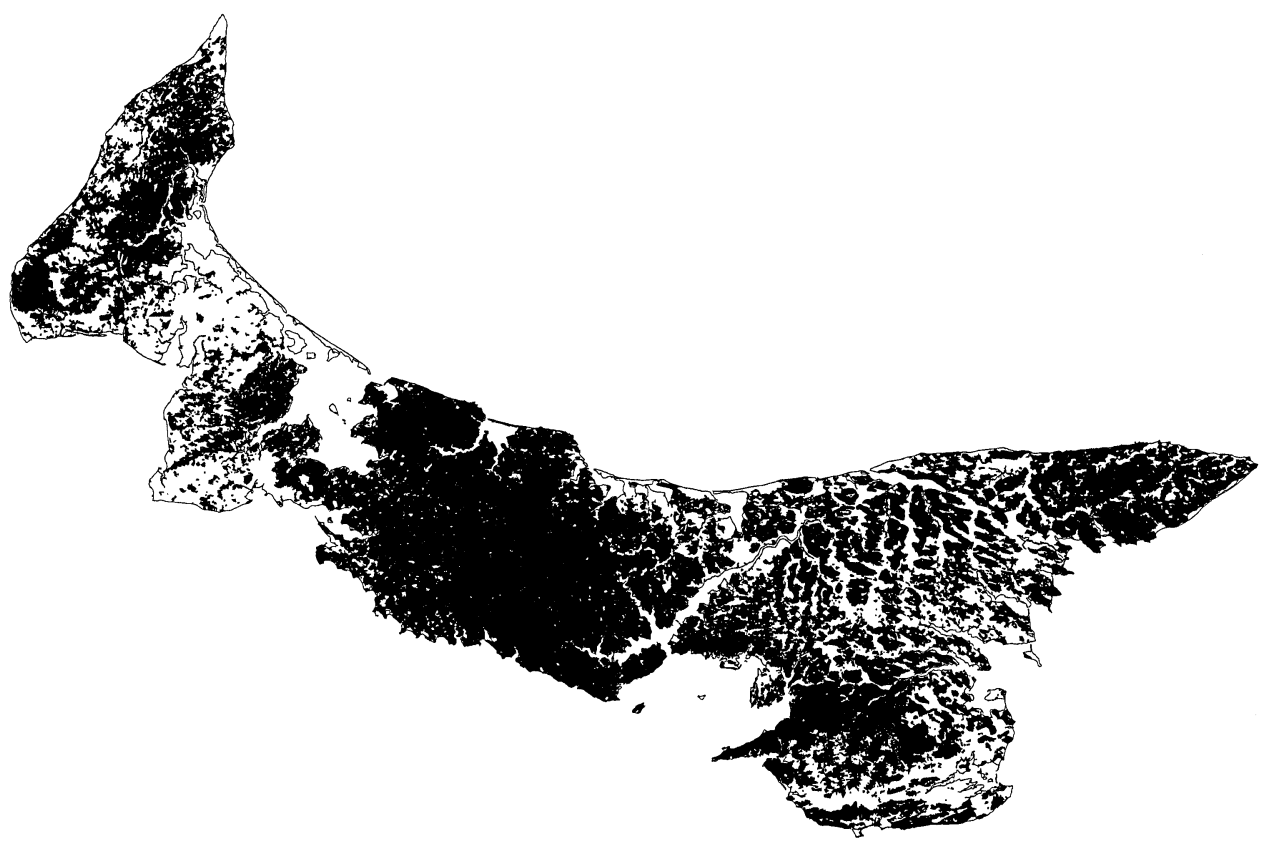

FIGURE 8. The conjectured distribution of upland hardwood forest prior to European settlement - based on combining the distribution of upland hardwood stands in 1990 with that of well-drained soils as mapped by the Soil Survey of Prince Edward Island (MacDougall et al. 1988).

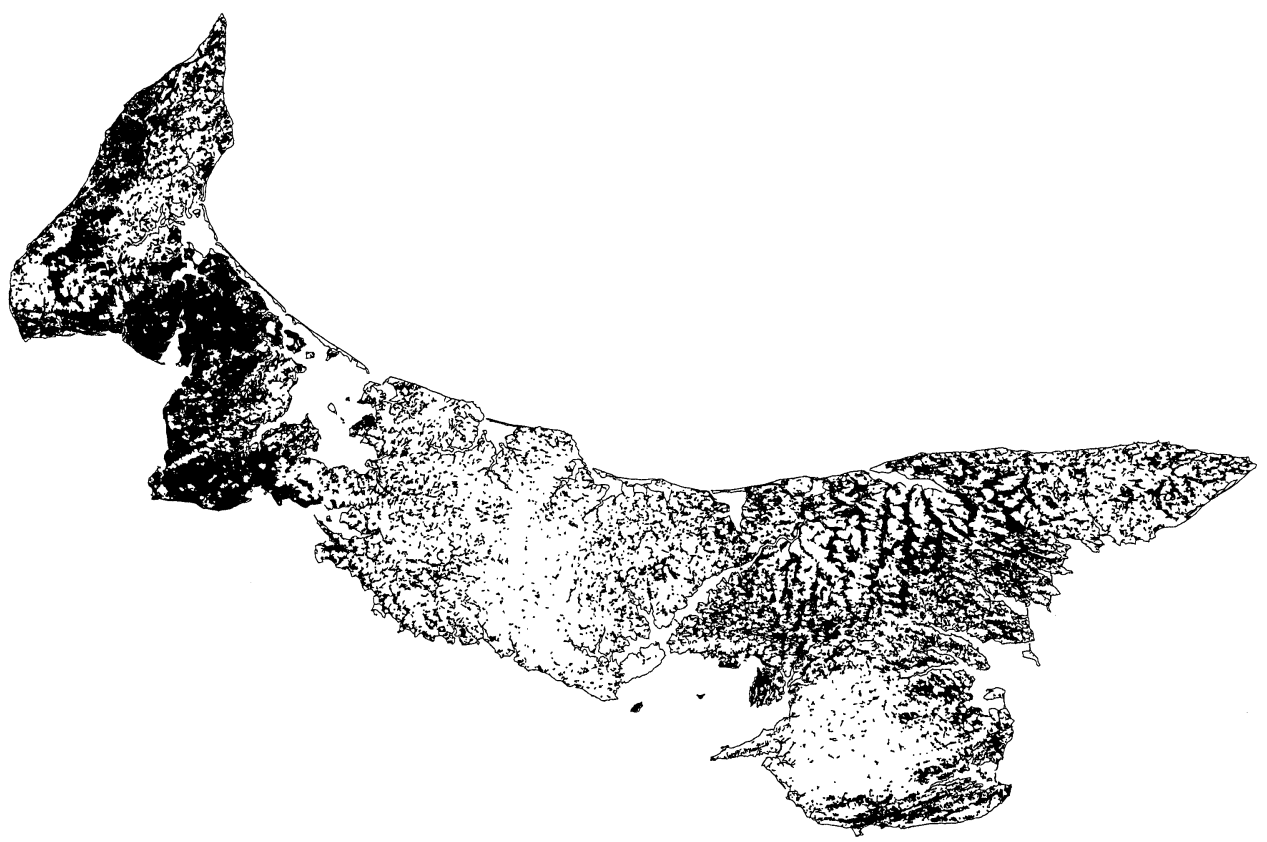

FIGURE 9. The conjectured distribution of wet rich woodland and Black Spruce forest prior to European settlement - based on combining the distribution of stands of these two forest-types in 1990 with the distribution of imperfectly- and poorly-drained soils (excluding stream complexes) as mapped by the Soil Survey of Prince Edward Island (MacDougall et al. 1988). 
occurring between the three pre-settlement foresttypes and the soils of different drainage properties: Table 5 shows for each drainage class the percentage of its "primary forest" component contributed by each of the three primary forest-types.

From Table 5 it is evident that well-drained coarsetextured soils (and to a less extent well-drained mediumtextured soils) have a strong association with upland hardwood forest (some $91 \%$ of the well-drained coarse soils and $69 \%$ of the medium soils have such a forest cover). By contrast, poorly and imperfectly drained soils are strongly associated with the two other presettlement forest types (wet rich woodland and Black Spruce forest) - some $94 \%$ of poorly-drained and $88 \%$ of imperfectly-drained sites carry such forests. However, although these two "wet" forest-types (as noted in Sobey and Glen (2002) and above), occupy soils of markedly differing chemical properties (in terms of $\mathrm{pH}$, base status and $\mathrm{C} / \mathrm{N}$ ratios), such chemical properties were not criteria used to characterize the soil series in the 1988 Soil Survey, and thus the soil series maps cannot be used to differentiate these two forest-types. Then there is the problem presented by the remaining soil drainage class, rapidly-drained soils (Table 5): $64 \%$ of such soils carry upland hardwood forest, but a significant proportion (30\%) has a cover of Black Spruce forest, more likely the dryer variant of the Black Spruce forest, shown in the TWINSPAN analysis (Sobey 1995) to have some association with rapidly-drained soils.

On the basis of the above relationships, Figure 8 is an attempt to show the approximate distribution of the pre-settlement upland hardwood forest, and presumably also the area that is capable of reverting to such forest in future. The map has been constructed by taking the 1990 distribution of upland hardwood forest (Figure 3) and adding to it the area occupied by welldrained soils (both coarse and medium-textured parent materials). It is likely that additional areas under rapidly-drained soils, particularly in the south-eastern hilllands, would also have carried some form of upland hardwood forest, but given the present state of our information, it is not possible at this stage to distinguish the hardwood-bearing areas of such soils from the Black Spruce areas.

Figure 9 is an attempt to show the area occupied before European settlement by the two wet forest-types (the wet rich woodland and the Black Spruce forest). It has been constructed by adding to the 1990 distribution of these forest-types (i.e., Figures 4 and 5), the combined distribution of poorly- and imperfectlydrained soils. Given the present state of the information incorporated within the G.I.S. database for the province, this is about as far as we can go for wet woodland. Distinguishing between these two woodland types would require data on the chemical properties of the soils. And, as noted above, Table 5 indicates that Black Spruce forest (presumably the dryer variant) will have also occurred on land having rapidly-drained soils. It is also likely that it is on such soils that the now largely extirpated pine forests of the island would have occurred in the past.

The picture that emerges from these maps is of an island that was mostly covered by upland hardwood forest, which formed a large continuous block in the central part of the island, with smaller but significant blocks in the western and eastern parts. By contrast, the wetter forest-types occurred at lower elevations in specific areas in the west and in a more scattered mosaic pattern in the east. It is thus on these lowland sites that the boreal element of the island's forests, in the form of Black Spruce forest, had a greater occurrence. Such a division of the landscape, based on soil moisture levels, between the northern hardwood forest and the boreal forest, appears to be typical in the borealbroadleaf ecotone (Pastor and Mladenoff 1992; Scott 1995).

It should be noted that compared with earlier attempts at mapping the pre-settlement forest (e.g., Stilgenbauer 1929; Loucks 1962) the maps presented here have a much finer scale of detail in their boundary lines. Also, the validity of the maps, as showing the forest distribution before European settlement, can be tested by comparing them with early historical descriptions of the forest, especially from the data contained in early maps and surveyors' field notebooks in the provincial archives. Not only would such a comparison allow us to ascertain the forest-types that actually occurred on many sites before forest clearance, it may also provide data on the fine-scale differences in the forests of such sites, in some cases even as to particular tree species. However this is beyond the scope of the present study. By contrast, the validity of the maps as pictures of the "future-natural" forest will only be testable from what happens if such areas revert to forest in future.

\section{Acknowledgments}

Doug Sobey thanks Professor Gerry McKenna, then Dean of Science at the University of Ulster, for enabling him to take six months leave from University duties in 1996 so that he could continue his research into the forests of Prince Edward Island, and the P.E.I. Department of Agriculture and Forestry, Forestry Division, for allowing full access to the 1990-1992 Forest Inventory data. He also thanks Harry Baglole of the Institute of Island Studies at the University of Prince Edward Island for supporting the continuance of the research associateship which enabled the use of library facilities at the University. Both authors thank Delmar Holmstrom of Agriculture Canada, Charlottetown, for providing advice on the grouping of the soil series into drainage classes.

\section{Literature Cited}

Anonymous. 1992. 1990/1992 Prince Edward Island forest inventory: Summary. Forestry Branch, P.E.I. Department of Energy and Forestry, Charlottetown, Prince Edward Island. 
Erskine, D. S. 1960. The plants of Prince Edward Island. Publication 1088. Canada Department of Agriculture.

Glen, W. M. 1997. Prince Edward Island 1935/1936 forest cover type mapping. Forestry Division, P.E.I. Department of Agriculture and Forestry, Charlottetown, Prince Edward Island.

Halliday, W. E. D. 1937. A forest classification for Canada. Canada Department of Mines \& Resources, Ottawa.

Loucks, O. L. 1962. A forest classification for the Maritime Provinces. Proceedings of the Nova Scotia Institute of Science 25: 85-167.

MacDougall, J. L., C. Veer, and F. Wilson. 1988. Soils of Prince Edward Island. Agriculture Canada, Charlottetown, Prince Edward Island.

Pastor, J., and D. J. Mladenoff. 1992. The southern borealnorthern hardwood border. Pages 216-240 in A systems analysis of the global boreal forest. Edited by H. H. Shugart, R. Leemans, and G. B. Bonan. Cambridge University Press, Cambridge, England.

Peterken, G. F. 1996. Natural woodland - ecology and conservation in northern temperate regions. Cambridge University Press, Cambridge, England.
Rowe, J. S. 1959. Forest regions of Canada. Canada Department of Northern Affairs and Natural Resources, Forestry Branch, Bulletin 123 [Reprinted 1972 with minor revisions as: Publication No. 1300, Canadian Forestry Service, Department of the Environment, Ottawa].

Scott, G. A. J. 1995. Canada's vegetation - a world perspective. McGill-Queen's University, Montreal and Kingston.

Sobey, D. G. 1995. Analysis of the ground flora and other data collected during the 1991 Prince Edward Island forest inventory. II. Plant community analysis. Prince Edward Island Department of Agriculture, Fisheries and Forestry, Charlottetown, Prince Edward Island.

Sobey, D. G., and W. M. Glen. 2002. The forests of Prince Edward Island: A classification and ordination using multivariate methods. Canadian Field-Naturalist 116: 585-602.

Stilgenbauer, F. A. 1929. The geography of Prince Edward Island. Ph.D. dissertation, University of Michigan, Ann Arbor, Michigan.

Watts, S. B. 1983. Forestry handbook for British Columbia (Fourth edition). University of British Columbia, Vancouver, British Columbia.

Received 20 May 2003

Accepted 4 November 2004

\section{APPENDIX 1. Summary descriptions of the five forest stand-types arising from the computer- sorting of 82957 forest stands.}

\section{UPLAND HARDWOOD FOREST 16170 stands (19.5\%); 55043 ha $(21.7 \%)$}

A stand-type of widespread occurrence on well-drained soils $(77 \%$ of its area is on such soils - plus an additional $13 \%$ on rapidly-drained soils), especially away from the coast and further back from roads, in the central and southeastern hill-lands, in the north-east peninsula, and in smaller specific areas in the east and west of the island. $94 \%$ of its area had a forest cover in 1935. The tree canopy is dominated by hardwoods (accounting for $85 \%$ of crown closure) - particularly Red Maple (36\%), with a notable contribution by Sugar Maple (22\%), and smaller amounts of Yellow Birch $(8 \%)$ and American Beech $(2 \%)$. There is also a significant component of White Birch (14\%) and Trembling Aspen (5\%). The minority conifer component $(15 \%)$ consists largely of Balsam Fir (9\%), with some White Spruce (5\%). The high contribution to crown closure by Red Maple, and the presence of White Birch and Trembling Aspen, are indicative of a high level of past, and we may presume, continuing, human disturbance. This stand-type is the direct descendant of the pre-European settlement upland hardwood forest postulated by Erskine (1960), though subject to varying levels of past and current human disturbance.

\section{Black Spruce Forest 8049 stands (9.7\%); \\ 33106 ha $(13.1 \%)$}

A rather localized stand-type occurring primarily on areas with poor and imperfect drainage $-78 \%$ of its area is on such soils - especially in specific parts of the west and east of the island. The tree canopy is dominated by conifers (comprising $87 \%$ of crown closure), above all Black Spruce (71\%) - with small contributions by Tamarack $(9 \%)$ and Balsam Fir $(5 \%)$. The $13 \%$ contributed by hardwoods comes largely from Red Maple (5\%) and Trembling Aspen (5\%). Most of the area $(77 \%)$ had a forest cover in 1935. This stand-type corresponds to the pre-settlement lowland Black Spruce forest of Erskine (1960).

\section{Wet Rich WoOdLAND 13863 stands (16.7\%); 42192 ha $(16.6 \%)$}

A stand-type almost completely confined to areas of poorlyand imperfectly-drained soils (95\% by ground area) especially in the west of the island, as well as parts of the east. The tree canopy is dominated by hardwoods (making up $65 \%$ of crown closure), but there is also a notable conifer contribution $(35 \%)$. The chief hardwood species are Red Maple (26\%), Trembling Aspen (21\%) and White Birch (13\%). (White Cedar, American Elm and White Ash are present at low levels). The main conifers are Black Spruce $(10 \%)$, White Spruce $(8 \%)$, Balsam Fir $(6 \%)$ and Tamarack $(5 \%) .76 \%$ of its area was under forest cover in 1935 . This stand-type appears to be a derivative of the pre-settlement lowland Red Maple forest of Erskine (1960) - though with considerable effects due to cutting and other disturbances.

\section{White Spruce Woods 22709 stands (27.4\%); 57982 ha $(22.9 \%)$}

A widely scattered stand-type occurring as small often fieldshaped parcels on well- and rapidly- drained soils $(78 \%$ by area is on such soils). It is prevalent in the central hill-lands and even more towards the east of the island. A high proportion of its area $(62 \%)$ was cleared land in 1935 . The tree canopy is dominated by a single species, White Spruce, at a high level of crown closure $(68 \%)$. The remaining species contribute only small amounts: Trembling Aspen (8\%), White Birch (6\%), Tamarack (6\%), Red Maple (5\%) and Balsam Fir (4\%). This stand-type corresponds to the successional "old field" White Spruce woods of Erskine (1960). 


\section{"Disturbed Forest"}

22166 stands $(26.7 \%)$; 65259 ha $(25.7 \%)$

This residual stand-type (i.e., that left over after the stands of the other four types had been selected) is widely scattered, generally as small individual parcels (rather than large blocks), especially in the east and west of the island, notably on welland rapidly-drained soils $(75 \%$ by area occurred on such soils). The tree canopy has a slight predominance of hardwoods (54\%) - the principal species being Red Maple (20\%),
Trembling Aspen (19\%) and White Birch (13\%). Its large conifer component $(46 \%)$ is made up of Tamarack $(13 \%)$, White Spruce (10\%), Balsam Fir (9\%), Red Spruce (7\%) and Black Spruce (5\%). 33\% of its area was cleared land in 1935. This stand-type does not equate with any of Erskine's preEuropean forest-types - its species make-up and distribution suggest rather that it is largely a successional community heavily affected by past and continuing human exploitation. 